\title{
PANDEMONIUM IN PUBLIC HEALTH GOVERNANCE - A SNAPSHOT ON COVID CRISIS
}

KEY WORDS:

\section{Dr. M. Madhuri Irene}

\section{Covid-19 Corroding Into Human Existence- A Global Concern}

Covid-19 confirmed idiocy of intelligence and perils of powers exasperating the governance ethics of globe and castrated canons of human values. Corona blasted derisively the tenacity and techniques of 'Corona meter' in recording the victimization of health, wealth, economy, environment, education, and governance genuflection before the virility and victory of undaunted virus of SARS genesis. Learned gentry captioned the proliferation of Corona virus as 'Pandemic' of course with doubtful accuracy. The reference of pandemic as a term could have been justified in earlier historical cases of influenza, plague, ebola and SARs etc gracing the meaning of "a set of mutually exacerbating catastrophes" (referring to 1918 Influenza episode) but the present global Corona death dance devastating the material and mental health of individuals, institutions and society needs, probably, a better and appropriate word or phrase. Surprisingly, even before the blink of an eye, health crisis is transformed into multiple conundrums - economic, research, medical, political and governance mocking at all public and private institutions.

The WHO Coronavirus Disease (COVID-19) Dashboard noted with grave concern the surge of corona cases world-wide to be $3,35,56,424$, and deaths reported to be 10,06, 458 as on $29^{\text {th }}$ September 2020 , the holocaust equally embraced all the regions of the globe without any discrimination - race, religion, sex, caste, status and place of birth etc. Alas! Death levels all.

India touched $61,48,215$ reported cases and 96, 404 deaths as on $29^{\text {th }}$ September 2020, per day death count being more than one thousand.

Though the corona pandemic may not be annihilated totally, State and Subjects could possibly reduce the severity and vigor of the prevailing predatory force of the virus. Sovereigns declared that Corona has come to stay with us and we have to live with it. The Director General of the W.H.O. has been kind enough to caution the world populace to be more careful of the impending onslaught of new types of viruses/diseases affecting the health of vulnerable sections of women and children; exhorted the global population to come together in solidarity to fight against the Covid-19 pandemic; and ensure continuity of supply of all necessary testing equipment with the support of governments and the private sector; to secure the supply and equitable distribution of these tests.

\section{Pandemics And Public Health Security}

Pandemic is the sudden outbreak and proliferation of debilitating or fatal infectious diseases caused by human to human or other natural elements like air or water, impacting a range of negative social, economic and political consequences. Pandemics do not respect international borders.

The Covid-19 pandemic created unprecedented disaster in terms of human lives and economic recession paralyzing trade and commerce, victimizing health workers, delivery of social services and livelihoods, complicating access, safety, supply chain logistics and financial flow. The short-term implications of this global challenge are evident everywhere, but the long-term consequences of the pandemic - how it will reshape health and development institutions, occupations, and priorities - are still difficult to imagine.

The Global Health Security Index, 2019 observed that the national health security throughout the globe is fundamentally weak. The GHS Index covering 195 countries assessed countries' health security and capabilities across six categories, viz Prevention, Detection and Reporting, Rapid Response, Health System, Compliance with International Norms and Risk Environment, pointed out that no country is fully prepared for epidemics or pandemics, and the average overall GHS Index score is found to be $40.2 \%$. India ranked $57^{\text {th }}$ with a score of 46.5 while China ranked at $51^{\text {st }}$ with a score of $48.2 \%$. Thailand ranked $6^{\text {th }}$ in health security while US, UK, Netherlands, Australia and Canada lead the top ranks.

Health care is no longer a national agenda, it's a global agenda and Public health is the art and science of preventing disease, prolonging life and promoting health through the organized efforts of society.

Public Health Care system is inclusive of Primary Health care centre which serves as the abode and first point of contact of patients with a health professional, like Primary Care physician, dentists, community nurses, pharmacists and midwives, where the patients may feel free to disclose their problems, and views with regard to the health.

Public Health Care throughout the globe is poised to vindicate healthy societies and citizenry by thwarting the health inequalities hosting on social stratification and unequal social, economic and political pitches. Public Health Care system is an instrument of social justice to be operated by both the ruler and ruled.

Now, Sustainable health is an offshoot of Sustainable Development Goals, a daunting task for all stakeholders, politicians, funding resources, insurance taxpayers and patients of all health systems.

Globalization excited great curiosities and controversies in all fields of human existence, and its impact on health care systems is being felt in all societies. While some historians found a global perspective to be liberating and allow to pursue their interests beyond conventional boundaries of time and space, some argued that global histories have tacitly endorsed the globalized medicine to be exploitative.

No doubt, the governments are taking steps to recover the economies from the impact of Corona virus pandemic, but a narrow focus on fighting the recession may have adverse effects on the environment and health. As such, health and sustainability should be at the heart of the economic response.

\section{Vaccine And Health Politics:}

Every development in medical science is fraught with new challenges and ethical dilemmas. The COVID-19 pandemic was preceded by a chain of public health emergencies, including epidemics in 2002, 2009, 2012 and 2014. They offered opportunities to learn how to plan for future outbreaks, and reflection by governments and multilateral agencies. The American bioethics professor Joseph Fins called the COVID-19 pandemic a "stress test for bioethics", 
acknowledging that even ethicists "ignored a tale of inequity unfolding around us".

There must be a deeper engagement with the politics of health, social and cultural determinants. No doubt, the Belmont report in 1979 laid down the principles of respect for persons, beneficence and justice, particularly in relation to vulnerable groups.

Anant Bhan, a bioethics and global health policy researcher and former president of the International Association of Bioethics, says that in crises like the present Covid-19 pandemic, all international and national bodies governing public health and research should formulate new guidelines to cover many issues in between the silos of medical practice, clinical research and public health, not to speak of numerous allied activities that the state governs.

See the present scenario. The manufacturing of Vaccine has been enjoying long gestations of, not of scientific approbations, but of political and pharmaceutical expediency without heeding to the colossal calamity of human loss.

Covaxin has been developed and manufactured by Bharat Biotech in collaboration with the ICMR ( $26^{\text {th }}$ July 2020$)$

Many prominent hospitals like King Edward Memorial Hospital Parel, and BYL Nair Hospitals, Mumbai Central have received approval from ICMR to start the clinical trials, including the phase II and phase III clinical trial of COVID-19 vaccine developed by the University of Oxford is all set to start in India. Indian pharmaceutical major Serum Institute of India has initiated the process, Though India has two indigenous vaccine candidates Covaxin by Bharat Biotech and ZyCOV-D by Zydus Cadila, our health minister Harsha Vardhan stated (31 Aug 2020) that COVID-19 vaccine in India may be ready by the year-end.

Russia has dashed across the finish line and seized the trophy for being the first nation to release a vaccine for Covid-19. It has been nicknamed "Sputnik 5",China claims clandestine possession of vaccine for Covid-19. To add to the confusion, 'Vaccine Vacillation' or 'Vaccine Politics' between promises and performance of leading nations prompts to think as to whether the actions of China and Russia or other western nations with regard to Vaccine accessibility tend to promote "Bio-ethics Nationalism", or "Vaccine Nationalism".

According to Dr. Jonathan Moreno, a renowned bioethicist, the corona-virus pandemic is placing unprecedented strains not only on economies and hospitals, but on bioethics. He further observed that 'National prestige and financial reward are uniquely and powerfully combined in a global pandemic that threatens to revise history. No doubt, viewing the present situation, the global bioethical rules of drug development are strained by the pandemic but not torn. When some western powers accelerate to de-globalize trade and commerce, it is to be seen whether bioethics could be an exception in times of corona pandemic for such de-globalization.

\section{INDIA INVIGORATING DEFENCE}

India's health security system is rickety in view of low allocation of budget for health system which is $1.5 \%$ of the GDP, nonemployment of qualified and regular health care professionals compounded by the low availability of health professionals i.e. 80 doctors for every one lakh of population for which the State has to take the responsibility. However, in 2020-21, the Ministry received an allocation of Rs 67,112 crore. This is an increase of $3.9 \%$ over the revised estimates of $2019-20$ (Rs 64,609 crore). The budget allocation for health during the year 2020-2021 i.e. $2.1 \%$ of the total budgetary outlay is disappointing.

Encouraging medical services in private sector at the cost public hospitals may result in death blow to poor and disadvantaged sections of the society, and in the recent past the government is favoring an insurance-based model to extend the public health care facilities to the people. As governments implemented necessary policies to slow the spread of the virus and people changed their behavior to limit their exposure, global supply chains started to shut down contributing to an economic catastrophe and the closure of schools and colleges resulted in academic catastrophe.

During corona period, India continues to face severe health crisis not related to Covid-19; continuous nationwide lockdown forcing of diversion of resources for curtailment of corona virus almost caused total disruption of non-Covid essential health services which are indispensable to maintain health indices. During March, 2020 there was disturbing drop-in maternal health services by $16.2 \%$, and attendant skilled home delivery and institutional delivery services by 7.7\%; diminishing child immunization in BCG and MMR by $7.5 \%$ and $34.3 \%$ respectively. Further, outpatient treatment of major non-communicable diseases of Oncology reduced by $64 \%$ and heart ailments by $51.8 \%$. The non-availability health care for non-covid patients will have long terms impact on non-Covid mortality and morbidity. The latest reports further dishearten the spirit of our health system, and the statistics as on August 2020 are given hereunder: - Side effects of a pandemic-Covid on routine health services.

20192020 Change\%

Newborn screened for defect@birth $\quad 20.9 \mathrm{~L} \quad 2.6 \quad 57.6$

$\begin{array}{lllll}\text { Outpatient-acute heart disease } & & 7.2 & 2.0 & -72.2\end{array}$

$\begin{array}{lllll}\text { " Cancer } & 5.0 & 1.4 & -72.3\end{array}$

Inpatient typhoid $\quad \begin{array}{llll}1.2 & 0.4 & -69.9\end{array}$

Inpatient-Asthma, COPD,resp.infns. $\quad 4.3 \quad 1.5 \quad-65.6$

$\begin{array}{llll}\text { Pregnant women free medicine JSSK } & 31.9 & 11.6 & -61.7\end{array}$

$\begin{array}{lllll}\text { Minor Surgeries } & 34.2 & 11.5 & -60.6\end{array}$

$\begin{array}{llll}\text { Major Surgeries } & 11.0 & 4.4 & -60.4\end{array}$

$\begin{array}{llll}\text { Lab TestDone } & 2111.7 & 851.2 & -59.7\end{array}$

Source $^{21}$

There have innumerable stories of the suffering of non-Covid patients across the country during the lockdown and after. The no. of immunized children fell by over 15 lakh in the three month period from April to June compared to the same months last year. The no. of institutional deliveries fell by 13 lakh. The registeresd no. of TB patients undergoing treatment fell to half of what it as last year. People seeking cancer treatment as outpatients fell by over $70 \%$. Hard won progress in national health goals in infant and maternal mortality suffered a jolt.

Every country realized its fragility of dependence on global institutions and other countries in responding to the exogenous shock of sudden outbreak of epidemics and pandemics, and also the need to maintain its life style corresponding to the global requirements.

\section{Preach And Practice With Global Perspective.}

It is evident that the Covid-19 pandemic infected millions of people and stalled economic activity throughout the globe. According to Global Economic Prospects report of June 2020, the baseline forecast envisions a 5.2 percent contraction in global GDP in 2020, The Global Economic Outlook During the COVID-19 Pandemic: A Changed World, while the International Monetary Fund says the global economy is expected to shrink by over 3 per cent in 2020 - the steepest slowdown since the Great Depression of the 1930s. Labour market worsened and nearly 20.5 million filing for unemployment in April 20 and 36 million in March 20. Economies such as the US, Japan, the UK, Germany, France, Italy and Spain are expected to contract this year by 5.9, 5.2, $6.5,7,7.2,9.1$ and 8 per cent respectively.

China's GDP dropped by 36.6 per cent in the first quarter of 2020 , while South Korea's output fell by 5.5 per cent, since the country didn't impose a lockdown but followed a strategy of 
aggressive testing, contact tracing and quarantining.

In Europe, the GDPs of France, Spain and Italy fell by 21.3, 19.2 and 17.5 per cent respectively.

While India's economic stimulus package is 10 per cent of its GDP, Japan's is 21.1 per cent, followed by the US (13 per cent), Sweden (12 per cent), Germany (10.7 per cent), France (9.3 per cent), Spain (7.3 per cent) and Italy (5.7 per cent).

New predictions of I.M.F. suggest a deeper recession and the strength of recovery is uncertain. But China is expected to register an economic growth of $1.3 \%$ this year and a whopping $8.1 \%$ in 2021 recording the highest economic growth rate in the world.

As per U.N. report, India's economy is forecast to contract by $5.9 \%$ in 2020 , warning that while growth will rebound next year, the contraction is likely to translate into a permanent income loss.

The Trade and Development Report 2020 by U.N. Conference on Trade and Development (UNCTAD) said the global economy will contract by an estimated $4.3 \%$ this year, leaving global output by year's end over $\$ 6$ trillion short. The world is grappling with the equivalent of a complete wipe out of the Brazilian, Indian and Mexican economies. And as domestic activity contracts, so goes the international economy; trade will shrink by around one-fifth this year, foreign direct investment flows by up to $40 \%$ and remittances will drop by over $\$ 100$ billion. UNCTAD expects South Asia to contract $4.8 \%$ in 2020 and recover to $3.9 \%$ in 2021 . India's GDP is forecast to contract $5.9 \%$ in 2020 and recover to $3.9 \%$ next year resulting in permanent income loss.

\section{Some of the issues to be pondered over for serious} consideration: -

a) Large investment in research for vaccines, therapeutics, and non-medical methods of prevention may save economic loss, loss of lives and livelihoods of millions of workers.

b) The pandemic should not become the new excuse for situational nationalism, or bioethics nationalism, isolationism, anti-immigration policies, and institutionalized racism, which may contribute to inequity in global health care.

c) The North - South and East - West paradigm is to be disfigured to promote cooperation among the states to fight against the common enemy i.e. the Covid-19 pandemic.

d) State should take to comprehensive, holistic and coordinated approach towards development, and address the health, social, economic and food impacts of the pandemic with a strategic public budget, if necessary with a key role to private finance.

e) Collaboration of Public Development Banks to address the collateral social and economic effects of health crisis by limiting the movement of people and shuttering nonessential business.

f) The Global Health Community must utilize the digital health technologies, Artificial Intelligence and telemedicine to reduce exposure to covid- 19.

g) We should not ignore waste of resources, inefficient and wasteful expenditure, but prioritize investments.

h) The governments must come to terms with their national resources, and work with resources of global health, finance, human rights institutions and donor agencies. Any public health crisis could only be mastered with communities at the center.

The social, economic and political consequences of the Covid-19 pandemic will redefine the health care system nationally and internationally. No doubt, we are too optimistic to see better health care in post-pandemic era, better collaboration between countries and regulatory bodies. The virus has seen the in-person doctor-led approach of healthcare in most countries transition into online experiences and interactions. The disruption caused by this pandemic is simply accelerating this change. Proper health governance indicates the strength of the State and Society.

"If we get governance right, we will be successful in the global response to COVID-19 and achieving global health security for the future."

\section{REFERENCES}

1. https://www.gatesfoundation.org/goalkeepers/report/2020-report/

2. https://www.who.int/dg/speeches/detail/who-director-general-sopening-remarks-at-the-media-briefing-on-covid-19---20-march-2020

3. https://www.devex.com/news/after-the-pandemic-how-will-covid-19transform-global-health-and-development-96936

4. www.ghsindex.org > wp-content > uploads > 2019/10 , 2019-Global-Health

5. Sidney Coupet, A Global Perspective on Health Care (10-10-2011) https://www.rwjf.org/en/library /articles-and-news/2011/10/a-globalperspective-on-health-care.html)

6. Sir Donald Acheson, (1988); WHO.@https://www.euro.who.int/en/healthtopics/Health-systems/public-health-services/public-health-services

7. See generally:http://www.wpro.who.int/chips/chip04/definitions.html

8. GLOBAL PERSPECTIVES IN HEALTH - Vol. 1 - Global Perspectives in Health Boutros-PierreMansourian@Encyclopedia of Life Support Systems (EOLSS)

9. O'Brien Patrick. Historiographical Traditions and Modern Imperatives for the Restoration of Global History.J. Global Hist. 2006; 1:3-39

10. Guerriero, C., Haines, A. \& Pagano, M. Health and sustainability in postpandemic economic policies. Nat Sustain 3, 494-496 (2020). https://doi.org/10.1038/s41893-020-0563-0

11. Usha raman, Where in India's COVID-19 Response Is the Moral Compass That Guides Governance? https://science.thewire.in/the-sciences/covid-19india-epidemic-ethics-communities/

12. (ibid note cited supra)

13. https://www.livemint.com/science/health/india-s-first-covid-vaccinecovaxin-update-encouraging-trial-results-so-far-11595735209134.html published on 26 th July 2020 .

14. https://www.livemint.com/https://www.livemint.com/(19th August 2020)

15. https://www.livemint.com/news/india/covid-19-vaccine-in-india-soonerthan-expected-emergency-authorisation-can-be-considered-says-icmr11597854273757.html

16. https://www.livemint.com/news/india/covid-19-vaccine-in-india-may-beready-by-the-year-end-says-health-minister-1 1598864928873.htm

17. https://www.bioedge.org/bioethics/russia-rushes-vaccine-dismayingbioethicists $/ 13519$

18. See generally https://www.livemint.com/https://www.livemint.com/; and

19. https://www.thehastingscenter.org/is-the-coronavirus-pandemicaccelerating-bioethics-nationalism/

20. https://health.economictimes.indiatimes.com/news/industry/vaccinenationalism-is-it-one-country-against-other-in-the-race-for-a-covid-19shot/77273522

21. https://www.thehastingscenter.org/is-the-coronavirus-pandemicaccelerating-bioethics-nationalism

22. Health Ministry. Rashtriya Bala Swasthya Karyakramam \& Janani Sisu Suraksha Karyakramam.

23. Times of India dated 31-08-2020. Hyd.Edition. (main page)

24. https://www.worldbank.org/en/news/feature/2020/06/08/the-globaleconomic-outlook-during-the-covid-19-pandemic-a-changed-world

25. https://www.statista.com/topics/6139/covid-19-impact-on-the-globaleconomy/

26. https://www.thehindu.com/news/national and covid-19impact-indianeconomy-forecast-to-contract--5.9-in-2020-un/article32675047.ece 